\title{
SISTEM HUKUM PENCEGAHAN PEREDARAN NARKOTIKA DI LEMBAGA PEMASYARAKATAN (STUDI KASUS DI LEMBAGA PEMASYARAKATAN CIPINANG)
}

Legal System on The Prevention of Narcotics Sirculation Inside of Correctional Facility (Case Study in Cipinang Correctional Facility)

\author{
Fuzi Narindrani \\ Peneliti Hukum Balitbang Hukum dan HAM Kemenkumham \\ JI. HR. Rasuna Said, Kuningan Jakarta Selatan \\ Email: narindranisujadi.348@gmail.com
}

Naskah diterima: 15 Maret 2017; revisi: 16 Mei 2017; disetujui: 16 Mei 2017

\begin{abstract}
Abstrak
Peredaran narkotika terutama lembaga pemasyarakatan sudah sangat marak, hal ini merupakan dampak dari hilangnya kontrol sistem hukum yang ada. Kondisi tersebut berdampak pada terbentuknya pandangan negatif masyarakat terhadap pelaksanaan penegakan hukum di Indonesia terutama di lingkungan institusi pemasyarakatan. Untuk itu diperlukan suatu upaya dan langkah nyata terhadap penanggulangan dan pemberantasan peredaran narkotika di dalam lembaga pemasyarakatan melalui perubahan sistem hukum. Sehingga permasalahan yang diteliti adalah bagaimana sistem hukum pencegahan peredaran narkotika di lembaga pemasyarakatan yang dapat mewujudkan keadilan untuk kedamaian. Dengan menggunakan metode penelitian yuridis empiris dengan data primer bersumber dari lembaga pemasyarakatan Cipinang, hasil penelitian menunjukan bahwa sistem hukum berupa legal structure, legal substance dan legal culture yang ada sudah sangat mengkhawatirkan, namun terdapat upaya perubahan berupa rehablitasi, terapi metadon, dan penghargaan bagi petugas. Hal terpenting yang perlu dilakukan oleh Kementerian Hukum dan Hak Asasi Manusia segera perlu memperbaiki sistem hukum yang ada di lembaga pemasyarakatan agar tercipta sistem pencegahan peredaran narkotika di lembaga pemasyarakatan dan menurunkan peredaran narkotika di lembaga pemasyarakatan.
\end{abstract}

Kata Kunci: narkotika, peredaran, sistem hukum

\begin{abstract}
Narcotics circulation inside of the correctional facility happens a lot, this is caused by the current legal system lack of control. This condition leads the society to see law enforcement process, especially within the correctional facility, negatively. Therefore, a real act towards the eradication of narcotics sirculation within the correctional facility through changing the law system is needed. The problem that will be examined in this study is how the legal system works to prevent the narcotics sirculation within correctional facility that can bring justice for peace. By using juricial empirical method and primary data taken from Cipinang Correctional Facility, the study finds out that the current legal system which comprises legal structure, legal substance, and legal culture is in a very cautious condition. However, some change are in the making such as rehabilitation, metadon therapy, and reward for officers. The most important thing to do by the Ministry of Law and Human Rights is to reform the legal system of the correctional facility that there will be a good narcotics sirculation prevention system within the correctional facility and reduce the narcotics sirculation there.
\end{abstract}

Keywords: narcotics, sirculation, legal system 


\section{A. Pendahuluan ${ }^{1}$}

Peredaran narkotika di Lembaga Pemasyarakatan (Lapas) sudah sangat marak. Sesuai dengan data Badan Narkotika Nasional (BNN) setiap tahun terdapat pengungkapan peredaran narkotika dari balik Lapas. Misalnya, pada tahun 2012, tujuh napi Nusakambangan terbukti menjadi otak peredaran narkotika 3,9 kilogram di Depok. Pada tahun 2013, seorang terpidana berinisial $\mathrm{FI}$ alias JF yang mendekam di Lembaga Pemasayarakatan Kembang Kuning, Nusakambangan, juga terbukti menyuruh seorang kurir berinisial BL untuk mendistribusikan sabu-sabu dan heroin di DKI Jakarta. Pada tahun 2014, terungkap dua terpidana dari Lapas Pontianak bernama Jacky Chandra dan Koei Yiong alias Memey terbukti menyuruh kurir bernama Nuraini untuk menyelundupkan $5 \mathrm{~kg}$ sabu-sabu dari Malaysia ke Indonesia. Pada tahun 2015, terpidana mati kasus narkotika, Freddy Budiman, diduga mengendalikan peredaran narkotika dari dalam Lapas Nusakambangan. ${ }^{2} \mathrm{Hal}$ ini menunjukkan bahwa penyalahgunaan narkotika di Indonesia sudah sampai pada tingkat yang sangat mengkhawatirkan khususnya yang terjadi di Lapas, kondisi tersebut diperkuat dengan adanya pernyataan dari Presiden Republik Indonesia yang menyatakan bahwa hampir 50\% peredaran narkotika di Indonesia terjadi dan dikendalikan dari dalam Lembaga Pemasyarakatan (Lapas) dan Rumah Tahanan Negara (Rutan) ${ }^{3}$ dan jumlah tahanan dan narapida kasus narkotika per April 2016 mencapai 80.360. ${ }^{4}$

Peredaran narkotika di Lapas merupakan peredaran gelap yang dilakukan secara tanpa hak atau melawan hukum. ${ }^{5}$ Hal tersebut menunjukan peredaran narkotika di Lapas merupakan kejahatan luar biasa dengan sistem jaringan yang rumit, sebagai contoh, transaksi yang dilakukan jaringan narkotika Freddy dilakukan dengan berbagai modus, seperti mingling (mencampurkan dana hasil tindak pidana dengan dana dari hasil kegiatan yang legal untuk mengaburkan sumber asal dananya), penyelundupan, hingga judi daring. Kondisi tersebut berdampak pada terbentuknya pandangan negatif masyarakat terhadap pelaksanaan penegakan hukum di lingkungan institusi Pemasyarakatan.

Peredaran narkotika di Lapas dalam perspektif hukum berkaitan erat dengan sistem hukum (legal system) yang ada di Lapas. Dengan kata lain bahwa peredaran narkotika di Lapas tidak akan terjadi apabila sistem hukumnya ${ }^{6}$ bekerja secara bersama dengan baik. Saat ini sistem hukum pencegahan peredaran narkotika 
telah banyak membawa 'korban', terutama narapidana yang selalu digerebek dan bagi petugas yang kena sanksi bahkan ada yang dipecat. Data menunjukkan bahwa di Semarang digerebek sebanyak 25 narapidana di Lapas kelas IA Kedungpane, ${ }^{7}$ Tiga narapidana Lembaga Pemasayrakatan Salambue kls IIB Kota Padang Sidimpuan, ${ }^{8}$ sedangkan petugas yang kena sanksi disebutkan oleh Kepala Kantor Wilayah (Kakanwil) Kemenkumham Aceh hingga tahun 2015 terdapat 70 pegawai sipir yang dikenakan sanksi administrasi karena lalai dalam bertugas. ${ }^{9}$ Dengan demikian antara stuktur hukum (legal structure), substansi hukum (legal substance), dan budaya hukum (legal culture) di Lapas harus saling mendukung.

Persoalan yang diteliti adalah bagaimana legal structure, legal culture dan legal substance sistem pencegahan peredaran narkotika di Lembaga Pemasyarakatan dapat mewujudkan keadilan untuk kedamaian di Lapas.

\section{B. Metode Penelitian}

Jenis data yang digunakan dalam penelitian ini adalah data sekunder dan data primer. Data sekunder berupa literatur sebagaimana tercantum di dalam Daftar Pustaka, Standar Pelayanan Pemasyarakatan, Pedoman Pelaksanaan Rencana Aksi Penanggulangan dan Pemberantasan Narkotika di Lapas, Karya ilmiah berupa jurnal, skripsi, thesis, disertasi, Peraturan Perundang-undangan. Data primer, berupa data kuantitatif yakni data yang diperoleh dari petugas Lapas dan pengunjung melalui penyebaran kuisioner atau daftar pertanyaan kepada seluruh responden. Penelitian ini bersifat deskriptif analitik yang ditujukan untuk mengungkapkan suatu masalah atau keadaan atau peristiwa sebagaimana adanya sehingga dapat mengungkapkan fakta yang sebenarnya. ${ }^{10}$ Dan analisa data yang diperoleh, baik data sekuder maupun data primer, selanjutnya dianalisis secara kualitatif.

\section{Pembahasan}

Temuan penelitian terhadap sistem hukum pencegahan peredaran narkotika sebagai berikut:

\section{Legal Structure pencegahan peredaran narkotika di Lapas Klas I Cipinang}

Struktur hukum (legal structure) merupakan institusionalisasi dari entitas-entitas hukum yang berkaitan dengan peredaran narkotika di Lapas. Penelitian ini menunjukkan bahwa sejarah singkat Lembaga Pemasyarakatan Kelas I Cipinang awalnya adalah unit pelaksana teknis dibidang pemasyarakatan yang berada dibawah Kementerian Hukum dan HAM RI cq. Direktorat Jenderal Pemasyarakatan dan bertanggung jawab langsung kepada Kantor Wilayah Kementerian Hukum dan HAM RI. Lapas Klas I Cipinang didirikan pada tahun 1912 oleh Pemerintah Hindia Belanda, seiring dengan

7 Lapas kelas 1 Semarang Digerebek, 25 Napi positif Konsumsi Sabu-Sabu, http://www.jawapos.com/ $\mathrm{read} / 2017 / 03 / 09 / 115058 /$ lapas-kelas-1-semarang-digerebek-25-napi-positif-konsumsi-sabu-sabu, (diakses 5 April 2017).

8 Digrebek 3 Napi di Lapas Sidempuan Pakai Sabu, http://www.metro24.co/headline/digrebek-3-napi-di-lapassidimpuan-pakai-sabu/ (diakses 5 April 2017).

9 Lalai Dalam Tugas, 70 Sipir Lapas Kena Sanksi, https://www.ajnn.net/news/lalai-dalam-tugas-70-sipir-lapaskena-sanksi/index.html, (diakses 5 April 2017).

10 Hadari Nawawi, Metode Penelitian Sosial, (Yogyakarta: Gajahmada Press, 1993), hlm. 31. 
perkembangan zaman dan lahirnya sistem pemasyarakatan di indonesia pada tahun 1964, bangunan yang dulunya digunakan sebagai Penjara bagi kaum pribumi dirubah fungsinya sebagai Lembaga Pemasyarakatan atau Lapas. Lapas Klas I Cipinang dibentuk berdasarkan Keputusan Menteri Kehakiman RI Nomor M.01.PR.07.03 Tahun 1985 tentang Organisasi dan Tata Kerja Lembaga Pemasyarakatan yang beralamat di Jl. Bekasi Timur No.170 Jakarta Timur. Bangunan Lapas Klas I Cipinang mengalami beberapa kali perubahan, hingga akhirnya perubahan dan renovasi total dilakukan pada tahun 2006. kini Lapas Klas I Cipinang berkapasitas 920 Orang terdiri dari 3 Blok Hunian yang mencakup 208 kamar. $^{11}$

Gambar 1. Struktur Organisasi Lapas Kelas I Cipinang

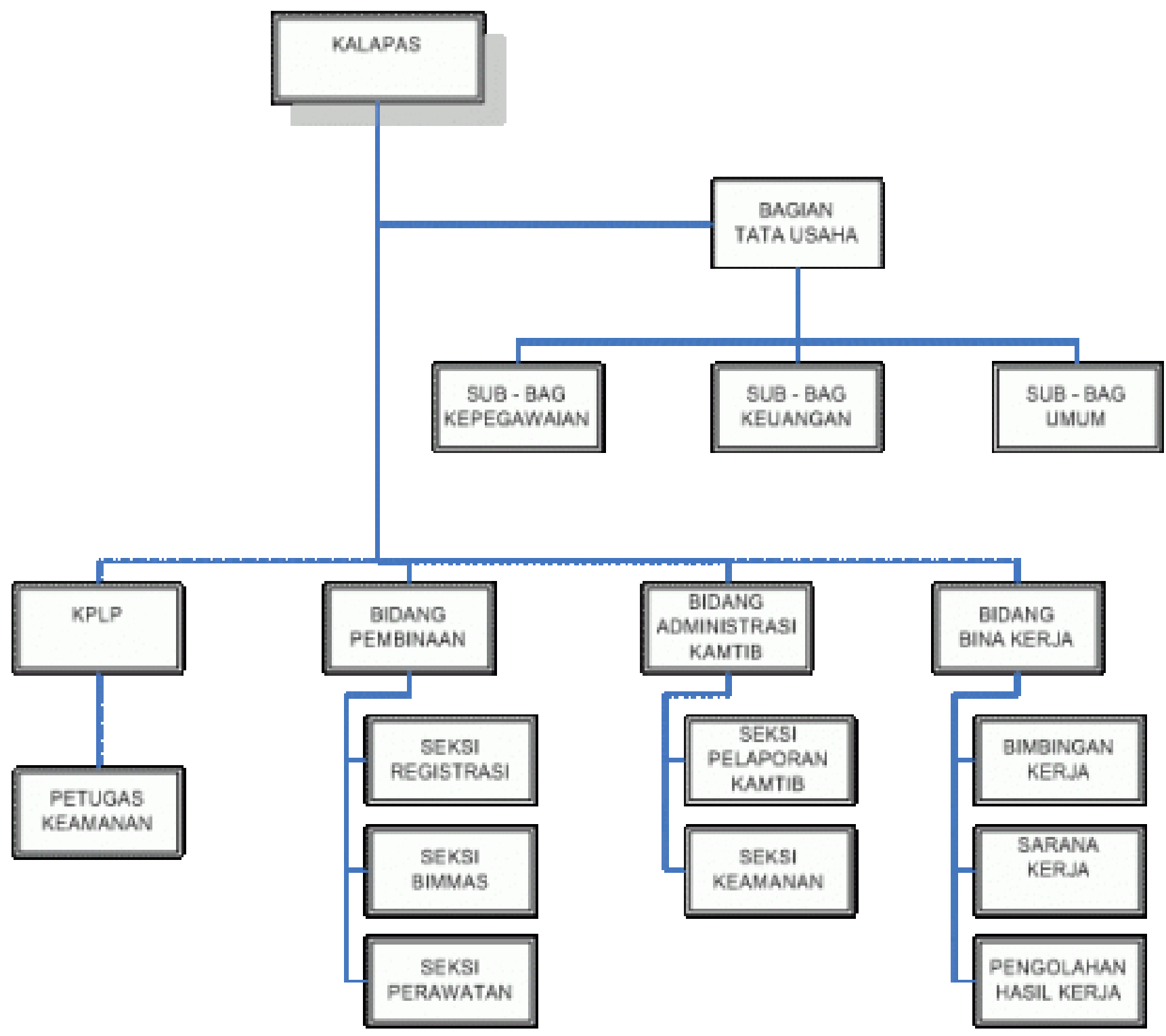

11 http://jakarta.kemenkumham.go.id/profil/upt/1042-lp-cipinang, diunduh hari Senin tanggal 8 September 2016 
Jumlah warga binaan pada bulan januari sampai dengan Agustus 2016 adalah sebagai berikut:

Tabel 1. Jumlah Warga Binaan Lapas Kelas I Cipinang

\begin{tabular}{llcccc}
\hline No & Periode & Tahanan \& Napi & Kapasitas & Persentase & $\begin{array}{c}\text { \% Over } \\
\text { Kapasitas }\end{array}$ \\
\hline 1 & Januari & 2920 & 880 & 332 & 232 \\
\hline 2 & Februari & 2930 & 880 & 333 & 233 \\
\hline 3 & Maret & 2926 & 880 & 332 & 232 \\
\hline 4 & April & 2954 & 880 & 336 & 236 \\
\hline 5 & Mei & 2906 & 880 & 330 & 230 \\
\hline 6 & Juni & 2884 & 880 & 328 & 228 \\
\hline 7 & Juli & 2838 & 880 & 322 & 222 \\
\hline 8 & Agustus & 2871 & 880 & 326 & 226 \\
\hline 9 & September & 2860 & 880 & 325 & 225 \\
\hline
\end{tabular}

Sumber: Laporan UPT Lapas Kelas I Cipinang

Data tersebut menunjukkan bahwa kapasitas Lapas hanya dapat menampung 880 warga binaan, namun setiap bulannya warga binaan yang di tampung selalu melebihi kapasitas.

Perkembangan Warga Binaan Lapas Klas I Cipinang mulai bulan Januari hingga bulan Agustus 2016 dideskripsikan dalam grafik berikut:

Grafik 1. Perkembangan Warga Binaan Lapas Klas I Cipinang

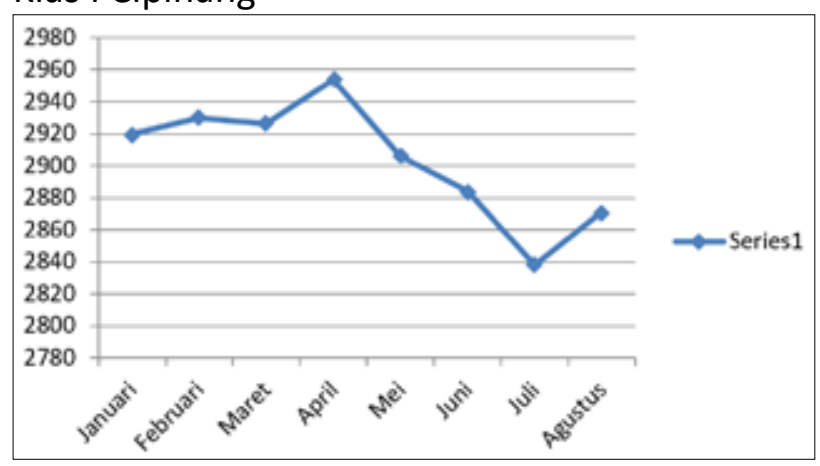

Jumlah warga binaan narkotika pada tanggal 30 Agustus 2016 adalah sebagai berikut:

Tabel 2. Warga Binaan Narkotika Lapas Klas I Cipinang

\begin{tabular}{cc}
\hline Jenis Kejahatan & Jumlah \\
\hline Narkotika & 2428 \\
\hline Lain-lain & 372 \\
\hline & 2800 \\
\hline
\end{tabular}

Data tersebut menunjukan bahwa jumlah keseluruhan warga binaan adalah 2800 dengan mayoritas jenis kejahatan narkotika, yakni sebesar 2428 warga binaan.

Dari gambaran kondisi Lapas yang ada, beberapa temuan kondisi di lapangan terkait dengan sistem pencegahan peredaran narkotika yaitu:

a) Alat pendeteksi logam (metal detector)

Hasil penelitian menunjukkan bahwa di Lapas Klas I Cipinang terdapat $60 \%$ alat 
pendeteksi logam (metal detector) yang kurang bagus dan $40 \%$ alat pendeteksi logam (metal detector) yang bagus. Hal ini sangat mengkhawatirkan, karena $40 \%$ responden yang menyatakan, dan harus diperhatikan dengan serius. Alat pendeteksi logam (metal detector) yang kurang bagus harus segera diperbaiki atau diganti dengan yang baru.

b) CCTV

Hasil penelitian menunjukkan bahwa di Lapas Klas I Cipinang terdapat 20\% CCTV yang kurang bagus dan $80 \%$ CCTV yang bagus. Hal ini sangat mengkhawatirkan, karena $20 \%$ responden yang menyatakan, dan harus diperhatikan dengan serius. CCTV yang kurang bagus harus segera diperbaiki atau diganti dengan yang baru.

c) Anjing Pelacak

Di Lapas Klas I Cipinang tidak tersedia anjing pelacak, tidak menggunakan anjing pelacak untuk deteksi narkotika. Untuk itu kiranya perlu dipertimbangkan untuk menyediakan anjing pelacak narkotika.

d) Ruang Sterilisasi

Hasil penelitian yang menunjukkan bahwa di Lapas Kelas I Cipinang terdapat 20\% Ruang Sterilisasiyang kurang bagus dan $80 \%$ Ruang Sterilisasiyang bagus. Untuk itu kiranya perlu dipertimbangkan untuk diperhatikan ketersediaan ruang sterilisasi, berfungsinya ruang sterilisasi, dan penggunakan ruang sterilisasi.

e) Profesionalitas SDM

Hasil penelitian menunjukkan bahwa di Lapas Klas I Cipinang terdapat 70\% SDM yang kurang profesional dan 30\% SDM yang profesional.Hal ini sangat mengkhawatirkan karena itu SDM di Lembaga Pemasyrakatan Kelas I Cipinang harus ditingkatkan profesionalismenya. f) Pengunjung

Hasil penelitian yang menunjukkan bahwa di Lapas Klas I Cipinang terdapat $50 \%$ pengunjung diperiksa kurang ketat, menunjukkan bahwa terdapat 50\% pengunjung yang diperiksa kurang ketat berpotensi untuk menyelundupkan narkotika.

Berdasarkan hal-hal di atas menunjukkan bahwa legal structure masih belum mendukung pencegahan peredaran narkotika

\section{Legal Culture pencegahan peredaran narkotika di Lapas Klas I Cipinang}

Budaya hukum (legal culture) adalah sikap dan nilai-nilai yang terkait, dengan tingkah laku. Say no to drug! Ini merupakan slogan yang sangat sederhana namun memiliki implikasi yang kompleks terkait dengan harapan yang harus diwujudkan, usaha berikut kebijakannya yang mesti diimplementasikan. Say no to drug, bukan hanya sebuah jargon, ini adalah tanggung jawab komponen bangsa untuk meningkatkan dan memberdayakan masyarakat menuju kehidupan yang sehat baik dari aspek mental, jasmani, maupun spiritual. Di seluruh dunia banyak program yang didirikan dengan maksud mencegah penyalahgunaan Narkotika, atau untuk mengobati mereka yang terkena narkotika melalui kepercayaan dan praktek-praktek agama tertentu. Pendekatan ini banyak dilakukan di Indonesia dan negara-negara berkembang lainnya. Di barat, agama tidak begitu menonjol dalam mencegah penyalahgunaan narkotika namun kita percaya bahwa program-program berbasis keagamaan benar-benar memiliki kepedulian ke arah sana.

Penyalahgunaan narkotika menyebabkan peningkatan HIV/AIDS

(Human 
Immunodeficiency Virus/Acquired Immune Deficiency Syndrome). Kekacauan mental, dan kejahatan yang pada gilirannya merusak sendi-sendi kehidupan sosial. Puluhan bahkan ratusan juta orang telah kecanduan narkotika. Di Indonesia Badan Narkotika Nasional (BNN) menaksir bahwa kira-kira ada 3,2 juta orang yang sudah terjerat ketergantungan Narkotika. Kendati persoalan narkotika muncul, pemerintahan kita memberi harapan bagi setiap orang, keluarga, masyarakat yang terpengaruh oleh penyalahgunaan narkotika sertayang terkait dengan persoalan kesehatan dan sosial. Riset menunjukkan bahwa kaum muda yang terlibat dalam komunitas keagamaan nampaknya tidak begitu rentan terhadap penggunaan Narkotika.

Temuan penelitian tentang legal culture di Lapas Klas I Cipinang bahwa jumlah pengunjung yang masuk kategori berbudaya kurang bagus adalah sebanyak 2 orang atau terdapat 20\% budaya yang kurang bagus. Dari temuan ini, meskipun jumlah pengunjung yang berbudaya bagus lebih banyak, namun masih ada juga pengunjung yang berbudaya kurang bagus. Hal ini cukup mengkhawatirkan, mengingat pengunjung yang berbudaya kurang bagus dikhawatirkan akan berpengaruh terhadap pengunjung yang berbudaya bagus. Tentu bukan sesuatu yang berlebihan jika kemudian dikatakan ada peluang bahwa $20 \%$ dari seluruh pengunjung adalah berbudaya kurang bagus, jika didasarkan pada temuan penelitian ini.

Hasil penelitian yang menunjukkan bahwa Lapas Klas I Cipinang masih dihuni oleh narapidana atau warga binaan pemasyarakatan
(WBP) dan tahanan, hal ini menunjukkan adanya Lapas yang tidak sesuai bahkan tumpang tindih. Fungsi Lapas adalah tempat untuk melaksanakan pembinaan narapidana dan anak didik pemasyarakatan. Untuk itulah sudah seharusnya dipisahkan antara narapidana dengan tahanan, apapun alasannya.

International Centre for Criminal Law Reform and Criminal Justice Policy (ICCLRCJP) mengemukakan bahwa kelompok tahanan (detainees/unconvicted prisoners) adalah kelompok khusus, yang juga memiliki hakhak khusus. ${ }^{12}$ Tahanan diartikan sebagai orang yang kemerdekaannya direnggut namun belum terbukti bersalah, sedangkan narapidana atau WBP, telah terbukti bersalah menurut putusan pengadilan. ${ }^{13}$ Karena sifatnya yang khusus dan berbeda dengan WBP, maka tahanan memiliki beberapa hak khusus, yaitu: ${ }^{14}$

a) Tahanan, yang belum terbuktibersalah, harus dipandang dan diperlakukan sebagai orang yang tak bersalah. Diatur dalam Aturan 84 dan Aturan 95 The Standard Minimum Rules for the Treatment of Prisoners (SMRTP);

b) Tahanan yang merupakan terdakwa (accused person), harus dipisahkan dari Narapidana, yaitu orang-orang yang terbukti bersalah (convicted person). Diatur dalam Pasal 10 International Covenant on Civil and Political Rights dan Aturan 85 SMRTP;

c) Tahanan, berdasarkan SMRTP, memiliki hak atas provisi-provisi khusus, misalnya: 1) mereka boleh memesan makanan yang mereka inginkan dari luar tahanan, pesanan itu dapat melalui administrasi

\footnotetext{
12 International Centre for Criminal Law Reform and Criminal Justice Policy. International Prison Policy Develepment Instrument (Canada: tp, 2001), hlm. 43.

13 United Nations, Human Rights in the Administration of Justice: A Manual on Human Rights for Judges, Prosecutors and Lawyers, (New York dan Jenewa: United Nations, 2003), hlm. 318.

14 Ibid.
} 
lembaga penahanan atau keluar tahanan yang bersangkutan; 2) jika mereka memakai seragam penjara, maka seragam mereka harus berbeda dengan seragam Narapidana;

3) tahanan harus ditawarkan kesempatan bekerja, namun tidak boleh dipaksa bekerja.

Penambahan gedung Lapas dan Rumah Tahanan (Rutan) dapat menjadi solusi untuk memisahkan antara narapidana dengan tahanan. Berdasarkan pasal 18 ayat (1) Peraturan Pemerintah Nomor 27 Tahun 1983, di tiap kabupaten atau kotamadya dibentuk Rutan. Namun kondisi yang terjadi di Indonesia adalah tidak semua kabupaten dan kotamadya di Indonesia memiliki Rutan dan Lapas, sehingga Rutan difungsikan pula untuk menampung narapidana seperti halnya Lapas. Hal ini juga mengingat kondisi banyak Lapas yang ada di Indonesia telah melebihi kapasitas, karenanya terdakwa yang telah menjalani hukuman di Rutan, yang seharusnya pindah dari Rutan untuk menjalani hukuman ke Lapas, banyak yang tetap berada di dalam Rutan hingga masa hukuman mereka selesai. Berdasarkan hal-hal diatas menunjukkan bahwa legal culture masih belum mendukung pencegahan peredaran narkotika

\section{Legal Substance pencegahan peredaran narkotika di Lapas Klas I Cipinang}

Adapun yang dimaksud dengan substansi hukum adalah aturan atau norma. Peredaran obat yang ada di Indonesia awalnya hanya digunakan untuk pengobatan medis, namun seiring perubahan zaman. Peredaran obat tersebut tidak digunakan untuk pegobatan medis tetapi dikonsumsi oleh orang-orang tertentu. Pada akhirnya peredaran obat yang disalahgunakan dinamakan peredaran narkorba yang di dalamnya terdapat peredaran narkotika. Peredaran narkotika sudah dalam taraf menghawatirkan bangsa Indonesia, dimana sekarang peredaran narkotika sudah mulai keremaja dan anak-anak. Hal ini tentunya harus mendapatkan penanganan serius oleh pemerintah, pada tahun 1997 pemerintah mulai serius membuat aturan hukum dengan diberlakukannya Undang-Undang Nomor 22 Tahun 1997 Narkotika dan Undang-Undang Nomor 5 Tahun 1997 tentang Psikotropika, kemudian direvisi menjadi Undang-Undang Nomor 35 Tahun 2009 tentang Narkotika.

Undang-Undang Nomor 35 Tahun 2009 tentang Narkotika jika dilihat dari aliran positivis hukum dikaji dari peredaran narkotika dikategorikan membahayakan bagi kesehatan, realitas yang terjadi dalam kehidupan masyarakat peredaran narkotika harus ada upaya penanggulangan dan pencegahan. Aturan hukum positif dalam undang-undang akan lebih efektif dengan berlakunya hukuman kurungan penjara, aliran positivisme hukum juga mengakui hukum diluar undang-undang. Dalam arti positivisme hukum tidak memisahkan antara hukum yang ada atau berlaku (positif), dengan hukum yang seharusnya ada. Hukuman kurungan penjara bagi pengedar narkotika sudah tepat penerapannya, bagi pengkosumsi narkotika hendaknya tidak dipenjara melainkan direhabilitasi. Oleh karena mengabaikan apa yang terdapat dibalik hukum, yakni berupa nilainilai kebenaran, kesejahteraan dan keadilan yang seharusnya ada dalam hukum.

Pasal 1 angka 6 Undang-Undang Nomor 35 Tahun 2009 tentang Narkotika (UU Narkotika), peredaran gelap narkotika dan prekursor narkotika merupakan setiap kegiatan atau serangkaian kegiatan yang dilakukan secara 
tanpa hak atau melawan hukum yang ditetapkan sebagai tindak pidana narkotika dan prekursor narkotika. Pasal 38 UU Narkotika lebih lanjut mengatur bahwa setiap kegiatan peredaran narkotika wajib dilengkapi dengan dokumen yang sah. Karena itu, tanpa adanya dokumen yang sah, peredaran narkotika dan prekursor narkotika tersebut dianggap sebagai peredaran gelap. Dalam rangka menimbulkan efek jera terhadap pelaku peredaran gelap narkotika dan prekursor narkotika, UU Narkotika mengatur mengenai pemberatan sanksi pidana, baik dalam bentuk pidana minimum khusus, pidana penjara 20 (dua puluh) tahun, pidana penjara seumur hidup, maupun pidana mati. Pemberatan pidana tersebut dilakukan dengan mendasarkan pada golongan, jenis, ukuran, dan jumlah narkotika. Bagi pengedar narkotika, setidaktidaknya terdapat 6 Pasal dalam UU Narkotika yang diancam dengan hukuman mati. Dalam hal kasus peredaran gelap narkotika di Lapas, ketentuan pidana dalam UU Narkotika ini berlaku baik bagi narapidana maupun petugas Lapas yang terbukti terlibat.

Terkait dengan peredaran narkotika di Lapas, konsideran Undang-Undang Nomor 12 Tahun 1995 tentang Pemasyarakatan (UU Pemasyarakatan) menyebutkan sistem pemasyarakatan yang dilaksanakan di Lapas merupakan rangkaian penegakan hukum yang bertujuan agar warga binaan pemasyarakatan menyadari kesalahannya, memperbaiki diri, dan tidak mengulangi tindak pidana sehingga dapat diterima kembali oleh lingkungan masyarakat, dapat aktif berperan dalam pembangunan, dan dapat hidup secara wajar sebagai warga yang baik dan bertanggung jawab. Sebagai peraturan pelaksanaan UU Pemasyarakatan, dikeluarkan Peraturan Menteri Hukum dan Hak Asasi Manusia Nomor 6 Tahun 2013 tentang Tata
Tertib Lembaga Pemasyarakatan dan Rumah Tahanan Negara (Permen No. 6 Tahun 2013). Pasal 4 angka 7 Permen tersebut melarang setiap narapidana atau tahanan menyimpan, membuat, membawa, mengedarkan, dan/ atau mengkonsumsi narkotika dan/atau prekursor narkotika serta obat-obatan lain yang berbahaya. Pelanggaran terhadap larangan ini termasuk larangan ini termasuk hukuman berat yang diatur dalam Pasal 10 ayat (3). Adapun dalam hal pelanggaran yang dilakukan oleh narapidana atau tahanan diduga tindak pidana, Kepala Lapas atau Kepala Rutan meneruskan kepada instansi yang berwenang (Pasal 17 Permen No. 6 Tahun 2013).

Pada tanggal 29 April 2016 Direktur Jenderal Pemasyarakatan mengeluarkan Surat Edaran Nomor Pas-182.PK.01.04.02 Tahun 2016 tentang Peningkatan Pencegahan Penyelunpan Barang-barang Terlarang di Lapas, Rutan dan Cabang Rutan. Surat edaran tersebut ditujukan kepada Kepala Kantor Wilayah Kementerian Hukum dan Hak Asasi Manusia RI Up. Kepala Divisi Pemasyarakatan di Seluruh Indonesia. Surat edaran tersebut digunakan sebagai pedoman dalam rangka peningkatan pencegahan penyelundupan barang terlarang di Lembaga Pemasyarakatan / Rumah Tahanan Negara.Surat edaran tersebut perlu ditingkatkan menjadi Peraturan Menteri Hukum dan Hak Asasi Manusia.Hal ini penting mengingat bahwa sampai saat ini belum ada Peraturan Menteri Hukum dan Hak Asasi Manusia yang mengatur mengenai pencegahan peredaran narkotika di Lapas dan Rutan. Berdasarkan hal-hal diatas menunjukkan bahwa legal substance masih belum mendukung pencegahan peredaran narkotika. 


\section{Sistem Pencegahan Peredaran Nar- kotika Guna Mewujudkan Keadilan Untuk Kedamaian}

Ada secercah harapan upaya mewujudkan keadilan untuk kedamaian di Lapas berupa rehablitasi, terapi metadon, penghargaan bagi petugas maupun pembentukan peraturan. Usaha mewujudkan keadilan untuk kedamaian dilakukan beberapa tindakan sebagai berikut:

\section{a) Rehabilitasi}

Jumlah warga binaan narkotika di Lapas Klas I Cipinang hingga Agustus 2016 berjumlah 2800 orang, dan dengan mayoritas jenis kejahatan narkotika yang berjumlah sebanyak 2428 warga binaan. Hasil wawancara menunjukkan bahwa Program Rehabilitasi di Lapas Klas I Cipinang telah dilakukan sebanyak 3 gelombang ${ }^{15}$. Masing-masing gelombang dilaksanakan selama 3 bulan, dan diikuti oleh 60 warga binaan. Syarat mengikuti rehabilitasi narkotika di Lapas Klas I Cipinang adalah warga binaan yang sekurangkurangnya 6 bulan menjelang bebas. Hal ini penting untukmenciptakan budaya warga binaan yang kuat pendiriannya, untuk tidak melakukan perbuatan penyalahgunaan narkotika kembali. Sehingga diharapkan setelah bebas, warga binaan yang telah mengikuti rehabilitasi tidak akan mengulangi perbuatannnya kembali.

Penyalahgunaan narkotika sebagian besar diawali dengan upaya coba-coba dalam lingkungan sosial. Semakin lama pemakaian, maka risiko kecanduan semakin tinggi. Jika terus dilanjutkan, maka dosis narkotika yang digunakan juga akan semakin besar untuk mencapai kondisi yang diinginkan (teler). Hingga pada titik takmampu melewatkan satu hari tanpa narkotika. Beberapa gejala yang menandakan seseorang sudah dalam tahap kecanduan antara lain keinginan untuk mengonsumsi narkotika setiap hari atau beberapa kali dalam sehari, dosis yang dibutuhkan semakin lama semakin besar, keinginan menggunakan narkotika tak bisa ditahan. Pengguna juga memastikan suplai narkotika terus tersedia dan bersedia menghabiskan uang hanya untuk membeli narkotika bahkan rela mencuri untuk itu.

Oleh sebab itu diperlukan rehabilitasi narkotika merupakan salah satu upaya untuk menyelamatkan para pengguna dari belenggu narkotika. Untuk itu ada beberapa tahapan rehabilitasi narkotika yang perlu dilakukan. Kunci rehabilitasi narkotika adalah melakukannya secepat mungkin. Untuk itu diperlukan dokter spesialis ketergantungan narkotika dengan bantuan psikiater ataupun konselor khusus di bidang ini. Sebagaimana pecandu lain, pecandu narkotika seringkali menyangkal kondisinya dan sulit diminta untuk melakukan rehabilitasi. Biasanya dibutuhkan intervensi dari keluarga atau teman untuk memotivasi ataupun membuat pengguna narkotika mau menjalankan rehabilitasi.

Penanganan melalui obat-obatan akan dilakukan melalui pengawasan dokter, tergantung dari jenis narkotika yang digunakan. Pengguna narkotika jenis heroin atau morfin, akan diberikan terapi obat seperti methadone dan buprenorfin. Obat ini akan membantu mengurangi keinginan memakai narkotika, yang diharapkan dapat mencegah penyakit seperti hepatitis $\mathrm{C}$ dan HIV hingga kematian. Obat jenis lain yang dapat digunakan untuk membantu rehabilitasi narkotika yaitu naltrexone. Hanya saja obat ini memiliki beberapa efek samping dan hanya diberikan pada pasien rawat jalan,

5 Wawancara dengan petugass kesehatan di Lapas Kelas I Cipinang tanggal 30 Agustus 2016 
setelah pengobatan detoksifikasi dilakukan di lokasi rehabilitasi. Naltrexone akan menghalangi efek narkotika berupa euforia (perasaan senang yang berlebihan dalam hal ini karena efek obat) dan ketagihan.

Pada tahun 2014 pemerintah Indonesia telah menerbitkan Peraturan Bersama tentang Penanganan Pecandu Narkotika dan Korban Penyalahgunaan Narkotika ke dalam Lembaga Rehabilitasi. Merujuk pada Undang-Undang Nomor 35 tahun 2009 tentang Narkotika dan Peraturan Pemerintah Nomor 25 tahun 2011 tentang Pelaksanaan Wajib Lapor Pecandu Narkotika, inilah dasar hukum untuk upaya dan langkah menyelamatkan pengguna narkotika.

Ada tiga tahap rehabilitasi narkotika yang harus dijalani. Pertama, tahap rehabilitasi medis (detoksifikasi) yaitu proses pecandu menghentikan penyalahgunaan narkotika di bawah pengawasan dokter untuk mengurangi gejala putus zat (sakau). Tahap kedua, yaitu tahap rehabilitasi non medis dengan berbagai program di tempat rehabilitasi, misalnya program therapeutic communities (TC), program 12 langkah dan lain-lainnya. Kemudian tahap terakhir yaitu tahap bina lanjut yang akan memberikan kegiatan sesuai minat dan bakat. Selain itu, pencandu yang sudah berhasil melewati tahap ini dapat kembali ke masyarakat, baik untuk bersekolah atau kembali bekerja.

Proses melepaskan diri dari narkotika untuk penggunanya tidaklah mudah. Selain menjalani rehabilitasi narkotika, mereka juga membutuhkan dukungan keluarga dan masyarakat agar dapat kembali menjalani hidup sehat dan produktif.

\section{b) Terapi Metadon}

Hasil penelitian menunjukkan bahwa adanya alternatif terapi Metadon dilakukan terhadap
16 warga binaan. Metadon disediakan pada Program Terapi Rumatan Metadon (PTRM), yaitu program yang mengalihkan pengguna heroin pada obat lain yang lebih aman. Metadon adalah opiat (narkotik) sintetis yang kuat seperti heroin (putaw) atau morfin, tetapi tidak menimbulkan efek sedatif yang kuat. Metadon bukan penyembuh untuk ketergantungan opiat. Selama memakai metadon, penggunanya tetap tergantung pada opiat secara fisik. Tetapi metadon menawarkan kesempatan pada penggunanya untuk mengubah hidupnya menjadi lebih stabil dan mengurangi risiko terkait dengan penggunaan narkotika suntikan, dan juga mengurangi kejahatan yang sering terkait dengan kecanduan. Dan karena diminum, penggunaan metadon mengurangi penggunaan jarum suntik bergantian, perilaku yang sangat berisiko penularan HIV dan virus lain. PTRM mempunyai dua tujuan pilihan. Tujuan pertama adalah untuk membantu pengguna berhenti penggunaan heroin, diganti dengan takaran metadon yang dikurangi tahap-demi-tahap selama jangka waktu tertentu. Tujuan kedua adalah untuk mengurangi beberapa dampak buruk akibat penggunaan heroin secara suntikan. Pilihan ini menyediakan terapi rumatan, yang memberikan metadon pada pengguna secara terus-menerus dengan takaran yang disesuaikan agar pengguna tidak mengalami gejala putus zat (sakaw). Metadon diberikan pada klien program dalam bentuk cairan (larutan sirop) yang diminum di bawah pengawasan di PTRM setiap hari. Setiap klien membutuhkan takaran yang berbeda, akibat perbedaan metabolisme, berat badan dan toleransi terhadap opiat. Beberapa waktu dibutuhkan untuk menentukan takaran metadon yang tepat untuk setiap klien. Pada awalnya, klien harus diamati setiap hari dan reaksi terhadap dosisnya dinilai. Jika 
klien menunjukkan tanda atau gejala putus zat, takaran harus ditingkatkan. Umumnya program mulai dengan takaran 20 mg metadon dan kemudian ditingkatkan 5-10 mg per hari. Biasanya klien bertahan dalam terapi dan mampu menghentikan penggunaan heroin dengan takaran metadon sedang hingga tinggi (60-100mg).

\section{c) Penghargaan (Reward)}

Bagi petugas yang dapat mengungkapkan peredaran narkotika di lembaga Pemasyrakatan sebaiknya diberikan reward yang memadai berupa uang, lencana,tidak hanya sekedar piagam.Lencana diperlukan oleh karena sebagai kebanggaan petugas.

Selain dari pada itu juga bagi petugas yang dijadikan saksi pengungkapan peredaran narkotika di lembaga pemasyarakatan sebaiknya diberikan fasilitas untuk menjadi saksi di pengadilan, misalnya, transpor dari dan ke pengadilan, uang makan.

\section{Penutup}

Sistem hukum pencegahan peredaran narkotika dalam mewujudkan keadilan untuk kedamaian di Lapas terus dibangun. Peredaran narkotika di Lapas merupakan dampak dari hilangnya kontrol sistem hukum. Hal ini ditandai dengan kondisi sistem hukum berupa legal structure, legal substance dan legal culture yang sudah sangat mengkhawatirkan, namun masih ada secercah harapan upaya mewujudkan keadilan untuk kedamaian di Lapas berupa rehablitasi, terapi metadon, penghargaan bagi petugas maupun pembentukan peraturan. Oleh sebab itu disarankan kepada Kementerian Hukum dan Hak Asasi Manusia untuk segera perlu memperbaiki sistemm hukum baik legal structure, legal substance maupun legal culture.

\section{Daftar Pustaka}

\section{Buku}

Amirin, Tatang M, Pokok-pokok Teori Sistem (Jakarta: CV Rajawali, 1986)

Direktort Jenderal Pemasyarakatan Kementerian Hukum dan Hak Asasi Manusia, Pedoman Pelaksanaan Rencana Aksi Penanggulangan dan Pemberantasan Narkotika di Lapas/Rutan (Jakarta: Ditjen PAS Kemenkumham, 2016)

Friedman, Lawrence M., American Law: An Introduction (New York: W.W.Norton \& Company, 1984)

Hornby, A.S., Oxford Advanced Learner's Dictionary of Current English (New York: Oxford University Press, 1974)

International Centre for Criminal Law Reform and Criminal Justice Policy. International Prison Policy Develepment Instrument (Canada: $\mathrm{t} p, 2001$ )

Nawawi, Hadari, Metode Penelitian Sosial (Yogyakarta: Gajahmada Press, 1993)

Karstedt, Susanne, dan Kai-D Bussmann. Social Dynamics of Crime and Control: New Theories for a World in Transition: Onati International Series in Law and Society (UK: Hart Publishing, 1999)

United Nations, Human Rights in the Administration of Justice: A Manual on Human Rights for Judges, Prosecutors and Lawyers (New York dan Jenewa: United Nations, 2003)

Winardi, Pengantar Tentang Teori Sistem dan Analisis Sistem (Bandung: Alumni, 1986)

\section{Internet}

Peredaran Narkotika di Lapas dan Rutan, (ysw) http:// metro. sindonews.com/read/1074490/170/ tekan-peredaran-narkotika-2-anggota-kostradberjaga-di-lapas-1451966573, (diakses $15 \mathrm{Mei}$ 2015)

Lapas kelas 1 Semarang Digerebek, 25 Napi positif Konsumsi Sabu-Sabu, http://www.jawapos. $\mathrm{com} / \mathrm{read} / 2017 / 03 / 09 / 115058 /$ lapas-kelas-1semarang-digerebek-25-napi-positif-konsumsisabu-sabu, (diakses 15 Mei 2015)

Digrebek 3 Napi di Lapas Sidempuan Pakai Sabu, http://www.metro24.co/headline/digrebek-3napi-di-lapas-sidimpuan-pakai-sabu/ (diakses 15 Mei 2015)

Lalai Dalam Tugas, 70 Sipir Lapas Kena Sanksi, https://www.ajnn.net/news/lalai-dalam-tugas- 
70-sipir-lapas-kena-sanksi/index.html, (diakses 15 Mei 2015)

Monika Suhayati, Penegakan Hukum Peredaran Narkotika di Lapas dan Rutan, Info Singkat (C) 2009, Pusat Pengkajian, Pengolahan Data dan Informasi (P3DI) Sekretariat Jenderal DPR RI www.dpr.go.id ISSN 2088-2351, http://berkas. dpr.go.id/ puslit/files/info_singkat/Info\%20 Singkat-VII-8-II-P3DI-April-2015-72.pdf, (diakses 15 Mei 2015)
50\% Peredaran Narkotika Dikendalikan Dari Lapas, http://pedomanbengkulu.com/2016/03/50peredaran-narkotika-dikendalikan-dari-lapas/, (diakses 15 Mei 2015)

\section{Peraturan}

Undang Undang Nomor 35 Tahun 2009 tentang Narkotika 
"Halaman ini dikosongkan" 